\title{
Effects of a cyanobacterial bloom (Cylindrospermopsis raciborskii) on bacteria and zooplankton communities in Ingazeira reservoir (northeast Brazil)
}

\author{
Marc Bouvy ${ }^{1, *}$, Marc Pagano ${ }^{1}$, Marc Troussellier ${ }^{2}$ \\ ${ }^{1}$ Institut de Recherche pour le Développement (IRD), IRD Center Bel Air, BP 1386, Dakar, Senegal \\ ${ }^{2}$ Lab Ecosystèmes lagunaires, ERS 2011 CNRS, Université Montpellier II, Case 093, Place E. Bataillon, \\ 34095 Montpellier cedex 5, France
}

\begin{abstract}
Species composition and seasonal succession of some planktonic components were studied through monthly samplings during 2 yr (1997 and 1998) in Ingazeira reservoir, northeast Brazil. Linked to the severe drought in this region (1997 El Niño event) was the dominance of the toxic filamentous cyanobacterium Cylindrospermopsis raciborskii in the phytoplankton in 1998 (96 to $100 \%$ of total phytoplankton biomass), with small proportions of heterocytes (12\% of filaments). A great part of the variability of the particulate organic carbon $\left(\mathrm{R}^{2}=83.9 \%\right)$ was explained by changes in the C. raciborskii carbon biomass. A more significant change in bacterial communities was observed in the post-bloom phase when biomass increased due to the appearance of larger sizeclasses of cell volume. This bacterial size structure may be the consequence of a strong pressure by bacterivores. Among the zooplanktonic groups, rotifers were numerically more abundant throughout the survey, but microcrustaceans, especially the copepods, contributed the highest proportion of the biomass. Despite the low edibility of $C$. raciborskii (large trichomes; mean of $97 \mu \mathrm{m}, \mathrm{n}=204$ ), zooplankton diversity increased during and after the bloom (March to December 1998). Our data suggest that rotifers and copepods were able to cut up and shorten the filaments to edible size for other zooplankton species, especially the small-bodied herbivorous cladocerans. Thus, in the studied ecosystem, the heterotrophic micro-organism community appeared to be able to develop a strategy to cope with a dominant and relatively inedible algal food source.
\end{abstract}

KEY WORDS: Bacteria · Phytoplankton · Zooplankton · Cylindrospermopsis raciborskii · Reservoir · Brazil

Resale or republication not permitted without written consent of the publisher

\section{INTRODUCTION}

Cyanobacterial blooms are increasingly frequent in continental aquatic systems around the world as a result of eutrophication. Frequently, these blooms can produce a wide range of toxins in water, posing a potential risk to livestock (Carmichael 1994, Codd 2000) and human health (such as the Caruaru tragedy in Pernambuco state, Brazil; Azevedo 1996). As often mentioned, the success of cyanobacterial species is explained by the facts that they are able to adapt their

*E-mail: bouvy@dakar.ird.sn physiological capacities to compete with other phytoplanktonic species (e.g., light and nutrients; Padisák 1997) and that they seem less edible for zooplankton and fish than other non-blooming algae (Gilbert 1996, Reynolds 1998). Cyanobacteria are often competitors at high turbidity when the underwater light levels are low (Padisák 1997), and this dominance can be highly resilient (Dokulil \& Mayer 1996). Many filaments are simply too large to be ingested by most zooplankters, and this can clog the feeding efficiency of filter feeders (Gliwicz \& Lampert 1990). The relative inedibility of cyanobacteria suggests that they may be favoured by the presence of zooplankton, which tend to eliminate 
competing algae that are more susceptible to grazing (Gragnani et al. 1999). Such selective grazing is often mentioned as an explanation for a shift to cyanobacterial dominance following the spring peak of zooplankton (Sarnelle 1993). Furthermore, the absence of large cladocerans such as Daphnia in tropical ecosystems facilitates the development of many cyanobacterial communities (Lazzaro 1997). The effect of toxins on different components of the microbial food web has been largely ignored in ecological studies (Christoffersen 1996, Sommaruga \& Robarts 1997), but they may affect several processes such as bacterial grazing by protists (Paerl \& Pinckney 1996). On the other hand, the cyanobacterial products can have a potentially important role in regulating bacterial development, as evidenced by the direct coupling existing between bacterioplankton abundance and cyanobacterial density (Wang \& Priscu 1994, Worm \& Sondergaard 1998).

Although the filamentous cyanobacterium Cylindrospermopsis raciborskii can often dominate phytoplankton assemblages (Padisák 1997), only a few investigations concern its impact on the other pelagic components (Hawkins \& Lampert 1989, Rothhaupt 1991, Branco \& Senna 1996, Mayer et al. 1997, de Souza et al. 1998, Bouvy et al. 1999, Borics et al. 2000). Its potential toxicity involving hepatotoxins (Ohtani et al. 1992) and neurotoxins (Lagos et al. 1999), is a threat to animal and human health, and its ability to form dense blooms appeared to decrease the biodiversity by eliminating all other phytoplankton species (Bouvy et al. 2000). Physical and climatological factors are responsible for the ecological determinants of the occurrence of $C$. raciborskii in reservoirs located in the Brazilian semiarid region (Bouvy et al. 2000, Nascimento et al. 2000). During the drought linked to the 1997 El Niño effects, a bloom of C. raciborskii, characterized by an average of $98 \%$ of coiled filaments, was observed in one of these reservoirs (Ingazeira reservoir) used mainly as a drinking water supply. In addition, neurotoxins have been detected from C. raciborskii extracts by intraperitoneal injection into mice (Molica et al. 1998, Bouvy et al. 1999). The dynamics of this cyanobacterial bloom were described over 2 yr (1997 and 1998) in a study of seasonal variations of environmental and phytoplanktonic parameters (Bouvy et al. 1999). In this paper, dealing with the same study period, the seasonal variations of carbon biomass of the main trophic components of this reservoir were analysed, with a special focus on the effects of the C. raciborskii bloom (March to September 1998) on 2 pelagic compartments: (1) the bacterial communities, which are now widely accepted as being the most important link between detritus, dissolved organic matter and higher trophic levels (Cole et al. 1988 and references therein); and (2) the zooplankton organisms, which are consid- ered as the major herbivorous components utilising phytoplankton as the main source (Boon et al. 1994).

\section{MATERIALS AND METHODS}

The Ingazeira reservoir $\left(8^{\circ} 34^{\prime} \mathrm{S}, 36^{\circ} 52^{\prime} \mathrm{W}\right)$ is situated in Pernambuco state, $250 \mathrm{~km}$ from the Atlantic Ocean (see details in Bouvy et al. 1999). Its surface is 130 ha at maximum capacity (theoretical volume of $4.6 \times 10^{6} \mathrm{~m}^{3}$ ). Its mean depth is $5 \mathrm{~m}$ with a maximum depth of $13 \mathrm{~m}$ in front of the dam. The climate of the region is classified as semi-arid with a historical annual average precipitation of $708 \mathrm{~mm}$ (1920 to 1985 period). However, in 1997, the annual value was lower $(507 \mathrm{~mm})$, and the precipitation decreased dramatically in 1998 with an annual rainfall of $123 \mathrm{~mm}$. These irregularities in precipitation were observed in all of the Brazilian semi-arid region, as a direct consequence of the 1997 El Niño event. The water level in Ingazeira reservoir decreased by $5.2 \mathrm{~m}$ between January 1997 (full total capacity) and December 1998 (20\% of the total volume).

Samples were collected at a fixed station in front of the dam at bimonthly intervals from January 1997 to March 1998. Between March and December 1998, samples were taken monthly in order to follow the cyanobacterial bloom. Water samples for particulate matter, bacteria, phytoplankton and chlorophyll concentrations were taken with a 21 vertical Niskin bottle at 2 sampling levels: 0.5 and $5 \mathrm{~m}$, near the bottom. Particulate organic carbon (POC) and nitrogen were detected by $\mathrm{CHN}$ analyser from samples (duplicates) retained on pre-combusted GF/F filters. Moran et al. (1999) reported that GF/F filters (mean pore size of $0.7 \mu \mathrm{m}$ ) let through only an amount of bacterial cells ranging from 6.5 to $10.3 \%$ of the total in a comparison of different types of filters used for the estimation of bacterial biomass from seawater samples. Samples for bacterial direct counts were fixed with buffered formalin ( $2 \%$ final concentration) and stained with $4^{\prime}, 6-$ diamidino-2-phenylindole fluochrome (DAPI $;$ final concentration of $100 \mathrm{\mu g} \mathrm{ml}^{-1}$ ) (Porter \& Feig 1980). Bacterial cells were counted by epifluorescence microscopy, and mean bacterial volumes were determined by measurements of up to 100 cells using photographic slides and a digitising table. Cell volumes were computed with the formula described by Krambeck et al. (1981). Carbon biomass was estimated assuming a con-

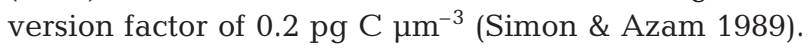
The frequency distribution of size classes can be obtained from the size-based Shannon index of diversity $\left(H=-\sum p_{i} \log _{2} p_{i}\right.$, where $p_{i}$ is the probability of size class $i)$, which indicates the size diversity of bacterial communities (Ruiz 1994). 
Phytoplankton analysis was described in Bouvy et al. (1999). Cell volumes based on measured dimensions were estimated for each species from geometric solid formula (Rott 1981). Carbon biomass was calculated using a carbon/dry weight ratio of 0.5 (Redfield 1958). Phytoplankton diversity was expressed by the Shannon-Weaver index (Shannon \& Weaver 1963) based on the biomass of each species according to the formula $H$ (bits) $=-\sum b_{i} / N \times \log _{2}\left(b_{i} / B\right)$, where $b_{i}$ is the biomass of the $i$ th species (as specific wet biomass) and $B$ is total biomass.

Zooplankton were sampled with conical nets $(30 \mathrm{~cm}$ diameter aperture, $80 \mathrm{~cm}$ height, $50 \mu \mathrm{m}$ mesh size). In order to sample the whole water column, the net was laid on the bottom and hauled 5 min later. The samples were preserved in buffered formaldehyde at a $5 \%$ final concentration. Organisms were counted on the whole sample or on subsamples estimated volumetrically using wide bore piston pipettes $(0.5$ to $5 \mathrm{ml})$ and including at least 300 individuals. Total length $(L$ in $\mathrm{mm}$ ) was measured under a dissecting microscope and converted into dry weight using common relationships and then into carbon using a carbon/dry weight ratio of 0.45 (Tables $1 \& 2$ ). Zooplankton diversity was expressed by the Shannon-Weaver index (see above).

The statistical software package SigmaStat (Jandel Corp.) was used to compute the Mann-Whitney tests and the Spearman rank correlation.

\section{RESULTS}

Relative abundance and biomass of the phytoplankton community have been described in a previous report (Bouvy et al. 1999). Cyanobacteria dominated the community throughout the survey (mean of 90.3 and $95.5 \%$ for the 2 depths studied). The population of Cylindrospermopsis raciborskii increased greatly between April and November 1998, reaching 96 to $100 \%$ of the phytoplankton biomass (Fig. 1). The Shannon diversity index was low during the study with a mean of 0.33 and 0.29 at depths of 0.5 and $5 \mathrm{~m}$, respectively. In 1998, minimum values of the index coincided with the dominance of $C$. raciborskii (Fig. 1). During the survey, more than $99 \%$ of the phytoplankton variability was explained by the $C$. raciborskii variation ( $\mathrm{n}=30, \mathrm{R}^{2}=0.993$; Fig. 2). This cyanobacterial species was represented by both straight and coiled forms, but the coiled form dominated with a mean of $98 \%$ during the survey (Fig. 3). The mean length of the filaments was $97 \mu \mathrm{m}$ with a range of 42 to $194 \mu \mathrm{m}$ ( $\mathrm{n}=204)$, and fresh volumes were close to $736 \mu^{3}$ for the straight form and 613 $\mu \mathrm{m}^{3}$ for the coiled form.

POC averaged 9.41 and $7.74 \mathrm{mg} \mathrm{C}^{-1}$ for the 2 studied levels, respectively, with higher values observed during and after the bloom until December 1998 (Table 3). Particulate organic nitrogen averaged 1.59 and $1.43 \mathrm{mg} \mathrm{N}^{-1}$ at 0.5 and $5 \mathrm{~m}$, respectively, with the highest values between April and September 1998. Values of C/N averaged 7.12 and 6.82, respectively, for the 2 studied levels, with the lowest values during the bloom of C. raciborskii between April and September 1998 (Table 3).

Table 2. Average length $( \pm \mathrm{SD})$ of the main crustaceans and estimates of their individual carbon weight according to length-weight relationships from the literature, and a constant C/dry weight (DW) ratio $=45 \%$. J: juveniles; Ad: adults. (1) Saint-Jean (Lake Chad, unpubl. data); (2) Bottrel et al. (1976); (3) Saint-Jean \& Bonou (1994)

\begin{tabular}{|lcccccc|}
\hline & Stage & $\mathrm{n}$ & Length $(\mathrm{mm})$ & Weight $(\mu \mathrm{gC})$ & Formula & Source \\
\hline Copepods & & & & & & \\
Notodiaptomus cearensis & Males + females & 32 & $0.975 \pm 0.148$ & 4.599 & $\mathrm{DW}=11.0 L^{2.9}$ & $(1)$ \\
Thermocyclops decipiens & Males & 40 & $0.520 \pm 0.619$ & 0.387 & $\mathrm{DW}=4.8 L^{2.63}$ & $(1)$ \\
& Females & 54 & $0.712 \pm 0.130$ & 0.883 & $\mathrm{DW}=4.8 L^{2.63}$ & $(1)$ \\
& Nauplii & 42 & $0.129 \pm 0.186$ & 0.008 & $\mathrm{DW}=2.5 L^{2.36}$ & $(2)$ \\
Cladocerans & $\mathrm{J}+$ Ad & 31 & $0.316 \pm 0.117$ & 0.124 & $\mathrm{DW}=12.97 L^{3.34}$ & $(2)$ \\
Ceriodaphnia cornuta & $\mathrm{J}+\mathrm{Ad}$ & 31 & $0.425 \pm 0.761$ & 0.454 & $\mathrm{DW}=9.0 L^{2.76}$ & $(3)$ \\
Moina micrura & & & & & & \\
\end{tabular}




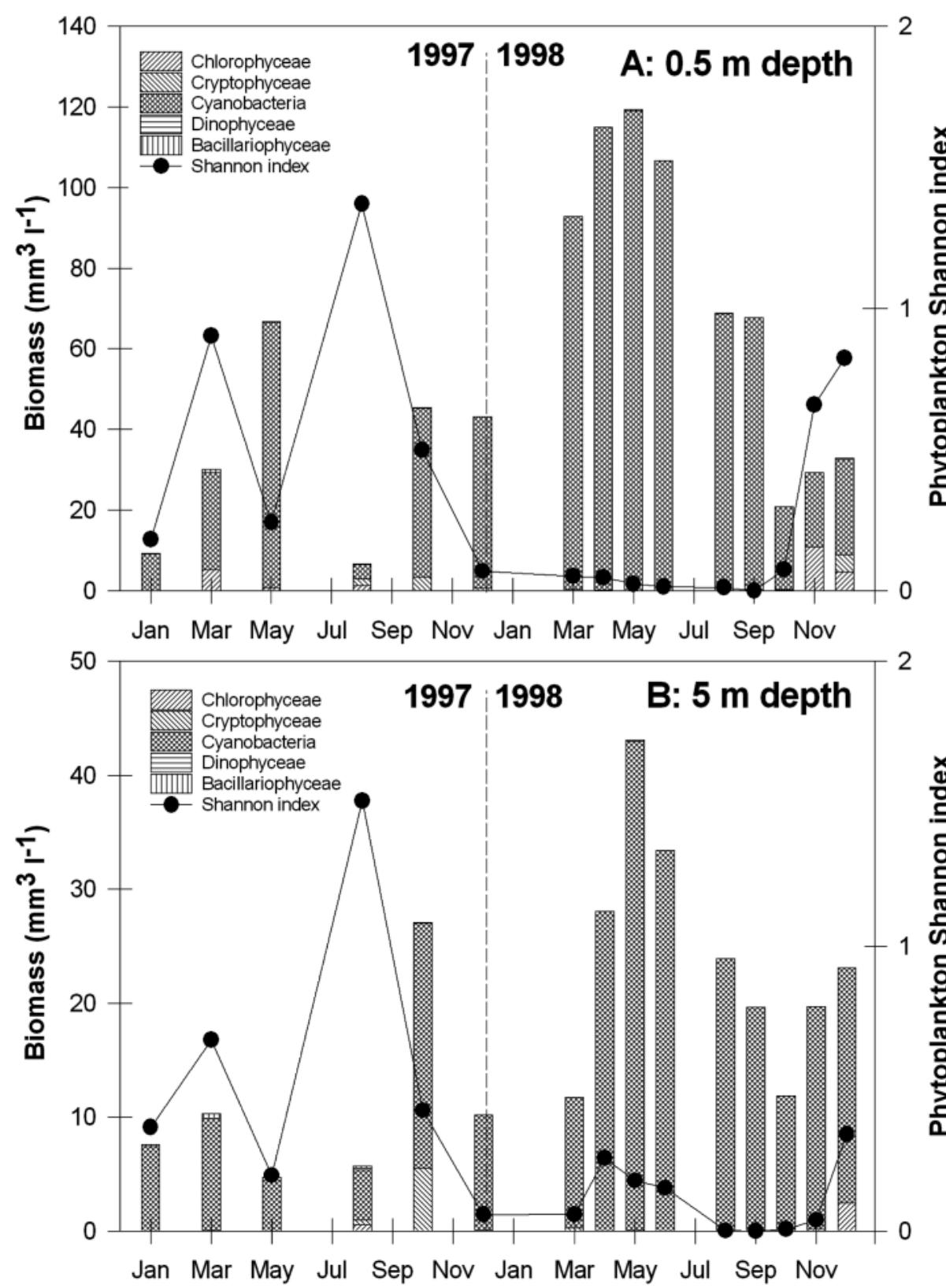

Fig. 1. Time course of phytoplankton biomass of different taxonomic groups, and of the Shannon-Wiever index at $0.5 \mathrm{~m}$ depth (A) and at $5 \mathrm{~m}$ depth (B) in 1997 and 1998
The carbon biomass of Cylindrospermopsis raciborskii accounted for a large proportion of the POC, ranging between $8.3 \%$ and $108.9 \%$ during the bloom (mean of $58.3 \%$; Table 4). This dominance of C. raciborskii was also detected by a significant correlation between the POC and C. raciborskii biomass before and during the bloom with $84 \%$ of the POC variability explained by the C. raciborskii biomass variations (Fig. 4). After the bloom, the accumulation of de tritical organic material linked to $C$. raciborskii degradation explained the low correlation between these 2 parameters throughout the survey $\left(R^{2}=0.212\right.$; $\mathrm{n}=15)$.
Changes in bacterial abundance at $0.5 \mathrm{~m}$ was limited, between $3.83 \times 10^{9}$ cells $1^{-1}$ in March 1997 and $5.65 \times 10^{10}$ cells $1^{-1}$ in May 1998 during the bloom (mean of $3.11 \times 10^{10}$ cells $1^{-1}$; Fig. 5). The same seasonal variation was observed near the bottom with a mean of bacterial abundance of $2.46 \times 10^{10}$ cells $\mathrm{l}^{-1}$. Bacterial biomass accounted for a very low proportion of the POC during the survey (mean: $0.20 \%$; Table 4 ). The bacterial communities was composed mainly of free rod-type forms with a mean cell volume of $0.030{\mu \mathrm{m}^{3}}^{3}\left(0.5 \mathrm{~m}\right.$ depth) and $0.032 \mu \mathrm{m}^{3}$ (0.5 m near the bottom). The highest cell volumes were noted at the end of the bloom and after the bloom of Cylin- 


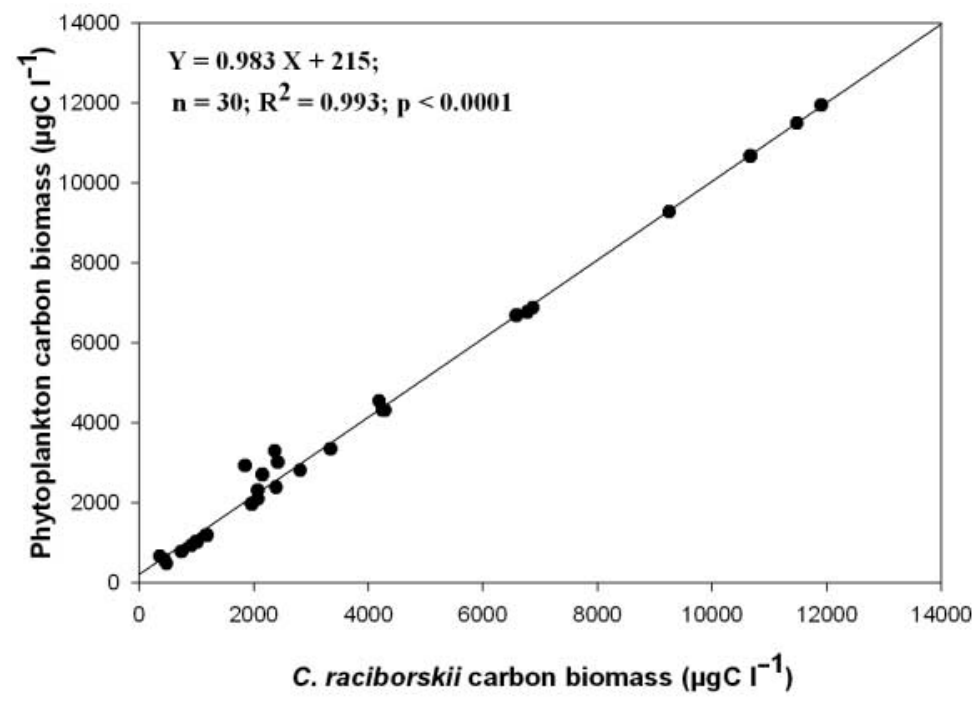

Fig. 2. Linear regression between Cylindrospermopsis raciborskii carbon biomass and phytoplankton carbon biomass at 0.5 and $5 \mathrm{~m}$ depth during the survey

drospermopsis raciborskii, with mean values higher than $0.040 \mu^{3}$ (Fig. 5). Patterns of bacterial biomass were similar to those of abundance, with a mean of $18.67 \mathrm{\mu gC}^{-1}$ at $0.5 \mathrm{~m}$. There was no significant difference (Mann-Whitney tests) between the 2 studied levels for each bacterial parameter (abundance, volume, biomass), suggesting that there was a great homogeneity of the water column in terms of bacterial dynamics.

The size-class distribution of bacterial cells was defined with an arbitrary size class of $0.01 \mu^{3}$ (Fig. 6). In 1997, all size classes were

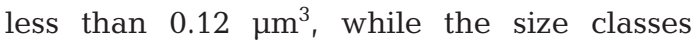
reached $0.16 \mu^{3}$ in December 1998. In March 1998, at the beginning of the bloom, there were only 3 size classes of cell volume with a mode of $0.015 \mu \mathrm{m}^{3}$. In December 1998 after the bloom, 14 size classes were present with the mode of bacterial volume rising to $0.050 \mathrm{\mu m}^{3}$. The lowest values of size-class diversity were observed in October 1997 and March 1998 and the highest after the Cylindrospermopsis raciborskii bloom (Fig. 7).

The total zooplankton biomass was low in 1997 (10 to $30 \mu \mathrm{g} \mathrm{C}^{-1}$ ) and increased in 1998, reaching the highest values (close to $116 \mu \mathrm{g} \mathrm{C}$ $\mathrm{l}^{-1} ; 1.25 \%$ of POC) in March, i.e., before the peak of Cylindrospermopsis raciborskii (Table 4). Afterwards, it decreased until June, peaked again in August and decreased until November, reaching values as low as those in 1997 (ca $20 \mu \mathrm{g} \mathrm{C} \mathrm{l}^{-1}$ ). A distinct change in the
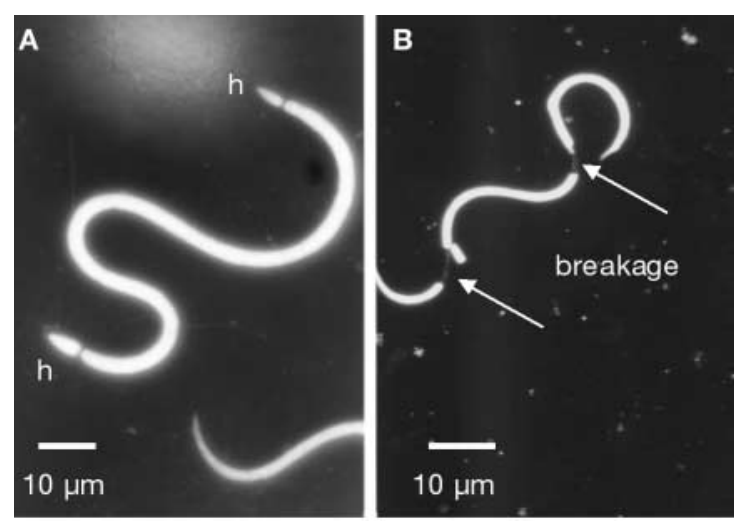

Fig. 3. Photomicrographs by epifluorescence microscopy showing trichomes of Cylindrospermopsis raciborskii. (A) Coiled trichome with 2 terminal heterocytes (h); (B) coiled trichome with 2 regions showing breakage of filaments by zooplankton after $48 \mathrm{~h}$ of grazing experiments

qualitative composition of this zooplankton biomass was noticed, especially in 1998 with the $C$. raciborskii bloom. Rotifers were dominant during the survey with a mean proportion of $85.4 \%$ of the total zooplankton abundance. Copepods and cladocerans accounted for an average of $5 \%$ and $9.5 \%$ of the zooplankton abundance, respectively. However, in terms of carbon biomass, copepods dominated the zooplankton community throughout the survey with a mean of $74.2 \%$, while rotifers had a mean of $16.9 \%$ (range between 8.7 and $35.3 \%$; Fig. 8). Cladocerans averaged a small proportion (mean of $8.9 \%$ ) but reached high biomass during the second zooplankton peak, coincid-

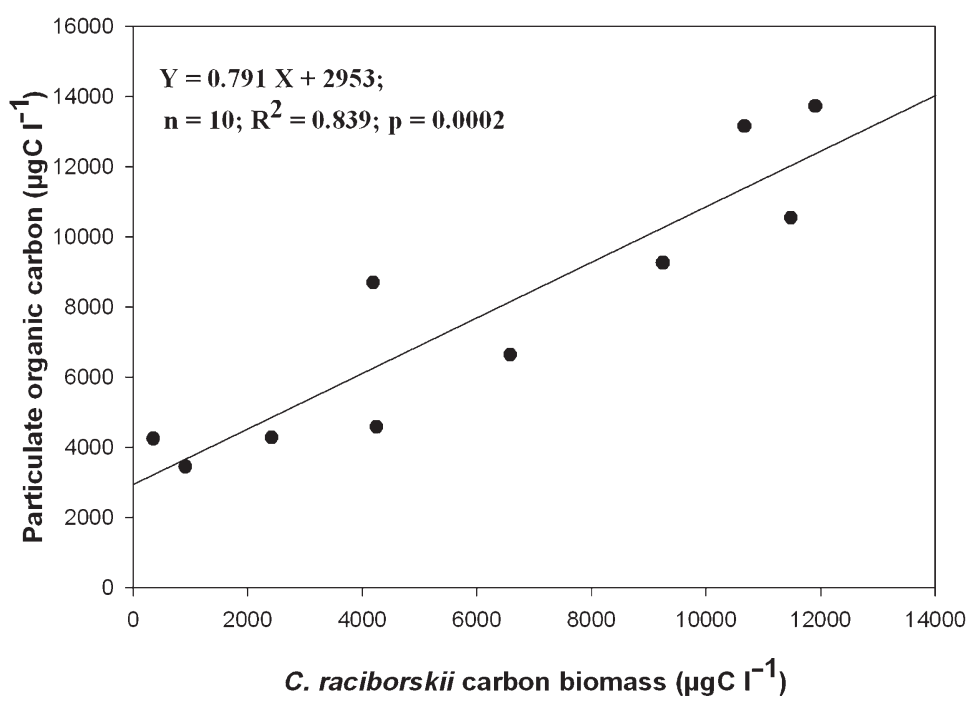

Fig. 4. Linear regression between Cylindrospermopsis raciborskii carbon biomass and particulate organic carbon at $0.5 \mathrm{~m}$ depth before and during the bloom $(n=10)$ 


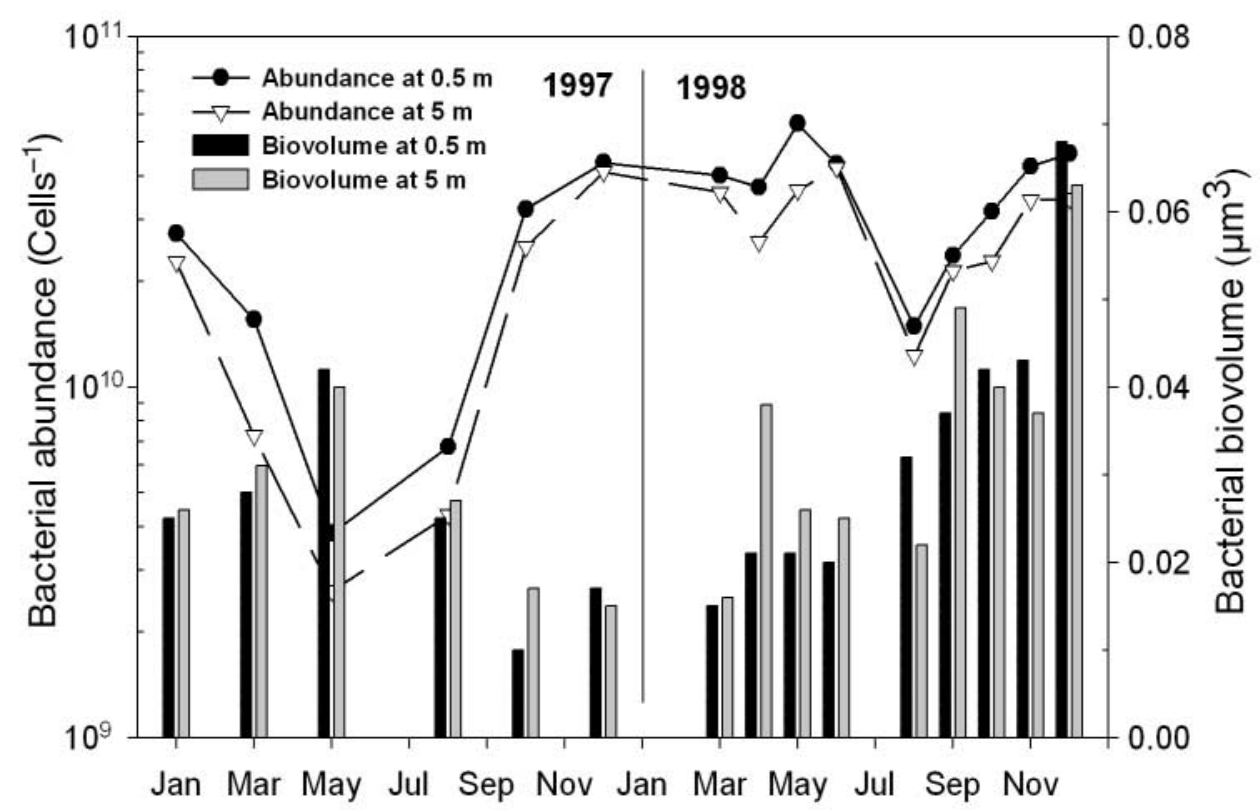

Fig. 5. Time course of bacterial abundances and biovolumes at 2 sampled depths $(0.5$ and $5 \mathrm{~m}$ depth) in 1997 and 1998

tion were evident, with biomass maxima recorded from March to October 1998 for Brachionus calyciflorus and from March to June 1998 for the genus Keratella, i.e., during the $C$. raciborskii bloom (Fig. 9). Other genera such as Polyarthra, Filina and Trichocerca were poorly represented throughout the study. Copepods were represented by 1 calanoid (Notodiaptomus cearensis) and 1 cyclopoid (Thermocyclops decipiens) with marked peaks between March and October 1998. For cladocerans, 2 species were identified: Moina micrura and Ceriodaphnia cornuta, with a notable peak of $M$. micrura be-

ing with the end of the cyanobacterial bloom in August 1998 (35.9 $\mathrm{\mu g} \mathrm{C}^{-1}$; $40 \%$ of total biomass; Fig. 8). Common genera of rotifers were Brachionus with 4 species (calyciflorus, plicatilis, angularis and falcatus) and Keratella with 3 species (longispina, tropica and 1 undetermined species). Patterns of seasonal biomass varia- tween August and November coinciding with the end of the C. raciborskii bloom (Fig. 9). The Shannon diversity function was low in 1997 (between 0.8 and 1) while the highest values were observed during and after the C. raciborskii bloom (between 1.29 and 1.52; Fig. 10).
Table 3. Concentrations of particulate organic carbon and nitrogen, and C/N ratio for each depth (0.5 and $5 \mathrm{~m}$ ) during the survey between January 1997 and December 1998. Average and coefficient of variation (\%) are reported

\begin{tabular}{|lrrrrrr|}
\hline $\begin{array}{l}\text { Date of } \\
\text { survey }\end{array}$ & \multicolumn{2}{c}{$\begin{array}{c}\text { Organic carbon } \\
\left(\mathrm{mg} \mathrm{C} \mathrm{l}^{-1}\right)\end{array}$} & \multicolumn{2}{c}{$\begin{array}{c}\text { Organic nitrogen } \\
\left(\mathrm{mg} \mathrm{N}^{-1}\right)\end{array}$} & \multicolumn{2}{c|}{ C/N ratio } \\
& $0.5 \mathrm{~m}$ & $5 \mathrm{~m}$ & $0.5 \mathrm{~m}$ & $5 \mathrm{~m}$ & $0.5 \mathrm{~m}$ & $5 \mathrm{~m}$ \\
\hline Jan 1997 & 3.45 & 2.91 & 0.55 & 0.43 & 7.34 & 8.00 \\
Mar & 4.28 & 3.38 & 0.59 & 0.54 & 8.43 & 7.38 \\
May & 6.64 & 5.00 & 0.88 & 0.79 & 6.88 & 7.41 \\
Aug & 4.25 & 3.75 & 0.57 & 0.45 & 8.62 & 9.72 \\
Oct & 8.70 & 6.45 & 1.51 & 1.15 & 6.74 & 6.59 \\
Dec & 4.58 & 4.18 & 0.72 & 0.69 & 7.39 & 7.90 \\
Apr 1998 & 10.54 & 10.34 & 2.14 & 2.21 & 5.75 & 5.48 \\
May & 13.73 & 6.06 & 2.34 & 1.13 & 6.86 & 6.27 \\
Jun & 13.15 & 15.72 & 2.46 & 2.91 & 6.25 & 6.30 \\
Aug & 13.81 & 14.50 & 2.67 & 2.70 & 6.04 & 6.27 \\
Sep & 10.00 & 9.67 & 2.03 & 2.03 & 5.74 & 5.55 \\
Oct & 12.12 & 6.77 & 1.76 & 1.35 & 8.05 & 5.83 \\
Nov & 13.14 & 10.00 & 1.83 & 1.79 & 8.39 & 6.51 \\
Dec & 13.33 & 9.68 & 2.17 & 1.81 & 7.18 & 6.25 \\
& & & & & & \\
Average & 9.41 & 7.74 & 1.59 & 1.43 & 7.12 & 6.82 \\
CV (\%) & 41.19 & 50.32 & 47.01 & 55.96 & 13.30 & 16.34 \\
\hline
\end{tabular}

\section{DISCUSSION}

In eutrophic shallow lakes, dominance of the filamentous cyanobacteria is a particularly important water quality problem, which can even persist throughout the year (Sas 1989). This case is reported by Huszar et al. (2000), who reported that cyanobacteria were dominant during $100 \%$ of the annual cycle in 8 productive tropical Brazilian waters. From our investigation of about 39 reservoirs located in Pernambouc state (Bouvy et al. 2000), we concluded that the singlespecies community structure is probably the ultimate manifestation of hypertrophy in turbid shallow reservoirs. The highly significant coefficient of determination between POC concentration and Cylindrospermopsis raciborskii biomass obtained in this study $\left(\mathrm{R}^{2}=0.84\right)$ confirms the 

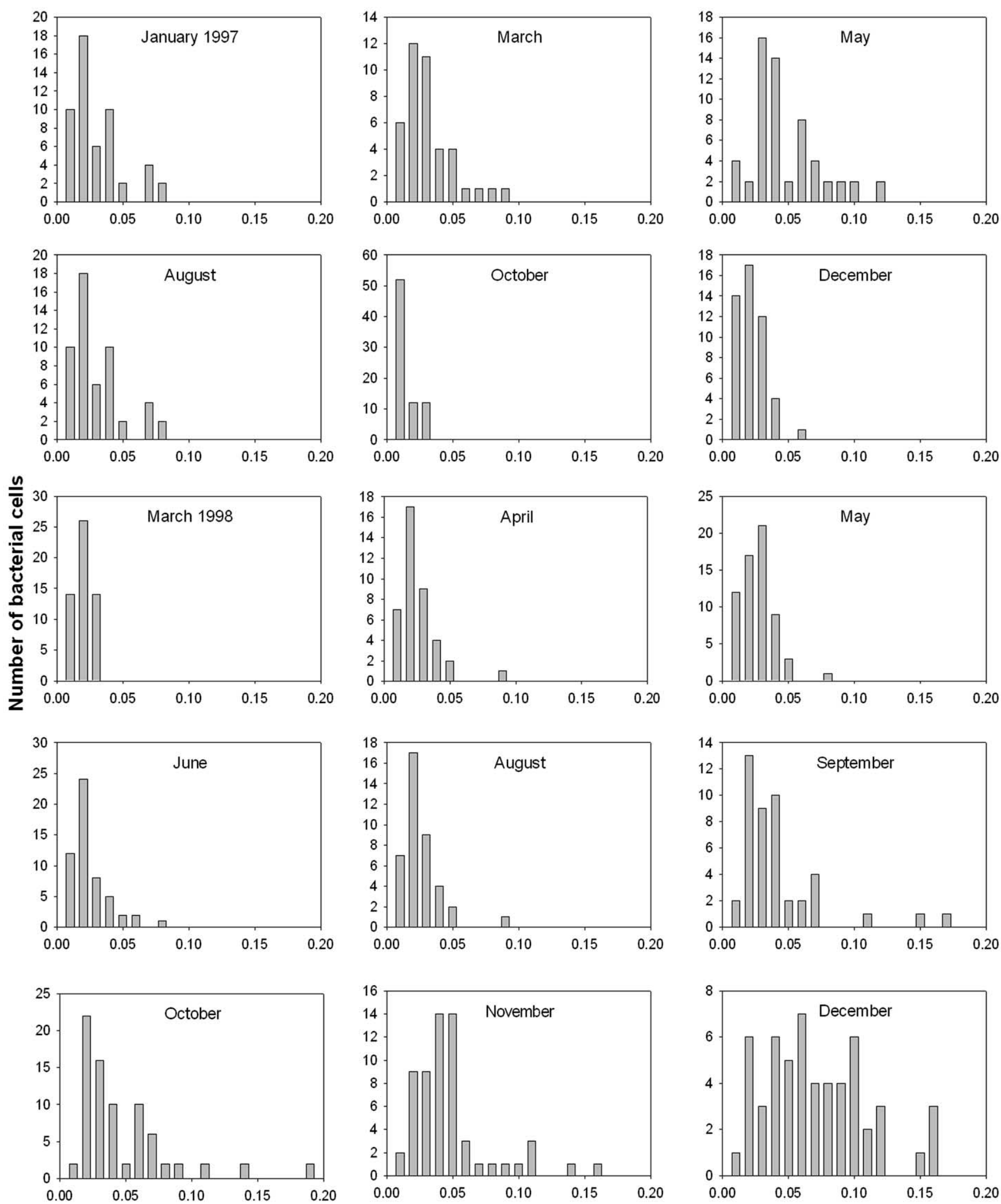

\section{Size class of cell volume $\left(\mu \mathrm{m}^{3}\right)$}

Fig. 6. Size-class distribution of cell volume of bacterial communities at $0.5 \mathrm{~m}$ depth for each month during the survey 


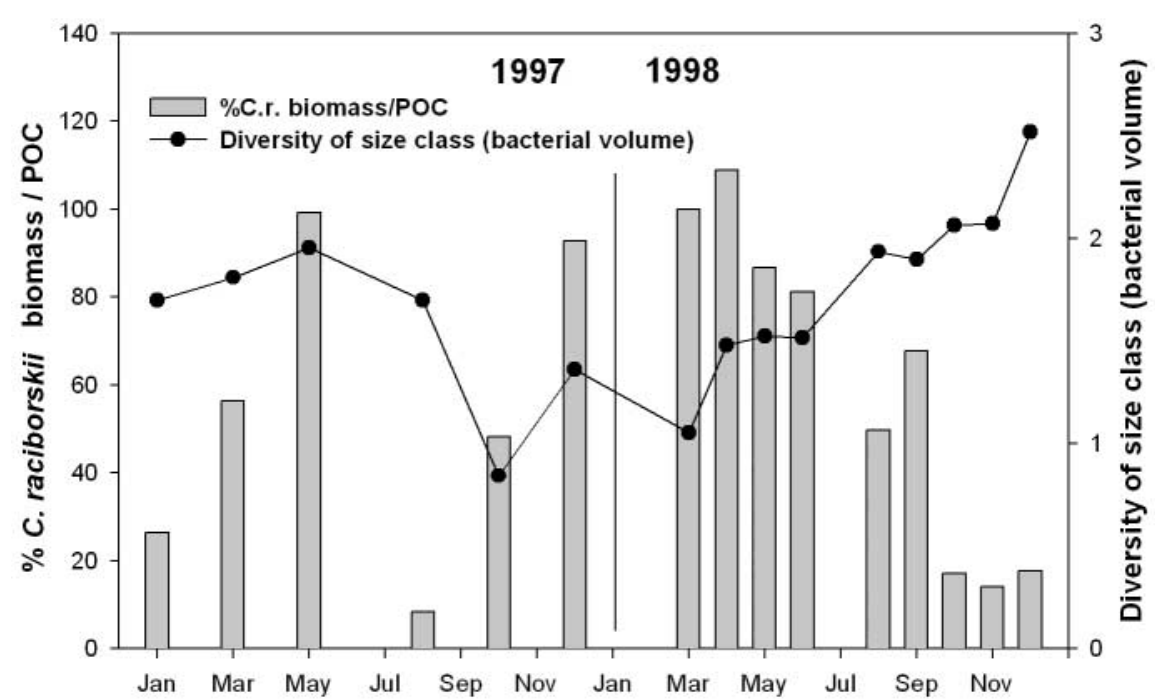

Fig. 7. Time course of the ratio of Cylindrospermopsis raciborskii biomass to POC, and the diversity of size class of the bacterial communities during the survey

\section{Effect of the bloom on bacterioplankton}

During the survey, total bacterial abundance was not significantly correlated $(\mathrm{p}>0.05)$ with the variations of Cylindrospermopsis raciborskii biomass. However, the highest cell volumes were observed during and after the bloom, explaining the increase of the bacterial biomass. In fact, this high biomass was due to the appearance of higher size classes of cell volume (Fig. 6). In March 1998, there were 3 size classes of cell volume at the beginning of the bloom, whereas up to 14 size classes were present after the bloom. The Shannon index values computed on the basis of size-class frequency show an increase in the

dominance of this cyanobacterium in the POC stock. The diversity Shannon-Weaver index was lowest during the bloom period with an evident trend of decrease in phytoplankton diversity coinciding with an increase in $C$. raciborskii dominance, accounting for close to $100 \%$ of the total algal composition over 9 mo.

Our study has focused on the effect of a Cylindrospermopsis raciborskii bloom on bacteria and zooplankton community structure because very little ecological research has been done on the effects of a toxic bloom on the other pelagic components.

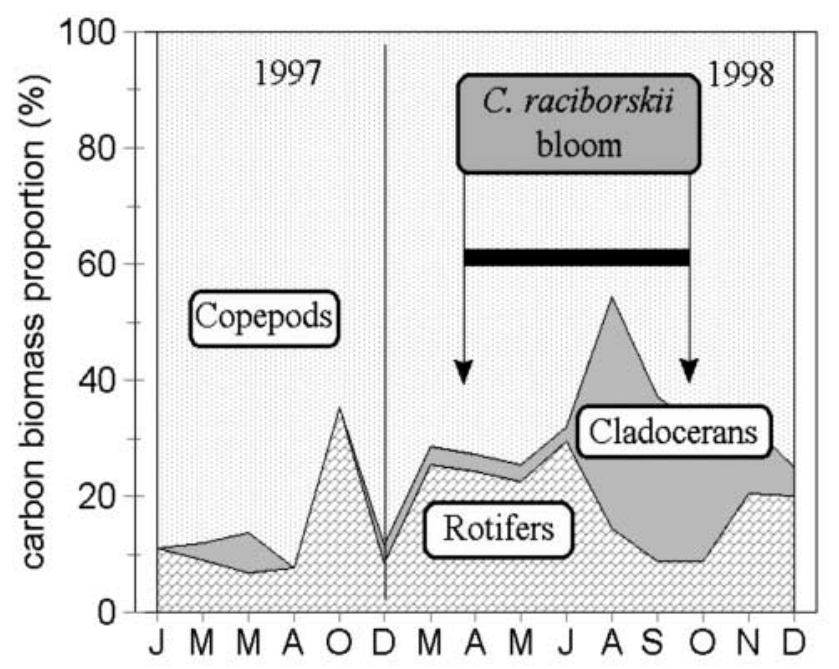

Fig. 8. Seasonal variations of the carbon biomass of the main species belonging to the 3 zooplanktonic groups (copepods, rotifers and cladocerans) during the survey from January 1997 to December 1998 diversity of bacterial size classes from the beginning to the end of the bloom (Fig. 7). Thus, bacterial communities exhibited their highest biovolumes and new cell size classes during and after the C. raciborskii bloom, suggesting that their control factors have been modified. This bacterial size structure may be the consequence of changes in the grazing pressure by bacterivores. Study of the size structure of planktonic bacteria from a hypereutrophic lake has already shown that the development of large forms can be a winning strategy under high protist grazing pressure (Sommaruga \& Psenner 1995). Jürgens \& Güde (1994) and Posch et al. (1999) showed that bacterial cell size appears to be an important factor influencing susceptibility to grazing, with a refuge at the lower and upper ends of the bacterial size range. All of this information suggests that the appearance of higher size classes can be explained by a strong bacterivorous pressure by nanoflagellates and the absence of other larger bacterivores. Based on the dilution method of Landry et al. (1984), the unique grazing experiment conducted in March 1998 in Ingazeira reservoir confirmed the impact of heterotrophic nanoflagellate pressure on bacteria with a high grazing value close to $81 \%$ of the bacterial cell production (unpubl. data).

If there is increasing evidence that standing stock of bacterial biomass is regulated by grazing, then bacterial growth is controlled by resource supply (del Giorgio et al. 1996, Posch et al. 1999). In Ingazeira reservoir, the highest abundances of bacteria were reported during the bloom, suggesting that the standing crop of labile organic matter issuing from cyanobacterial exudates can regulate bacterial growth. Wang \& Priscu (1994) showed that aquatic bacterial activity could be 

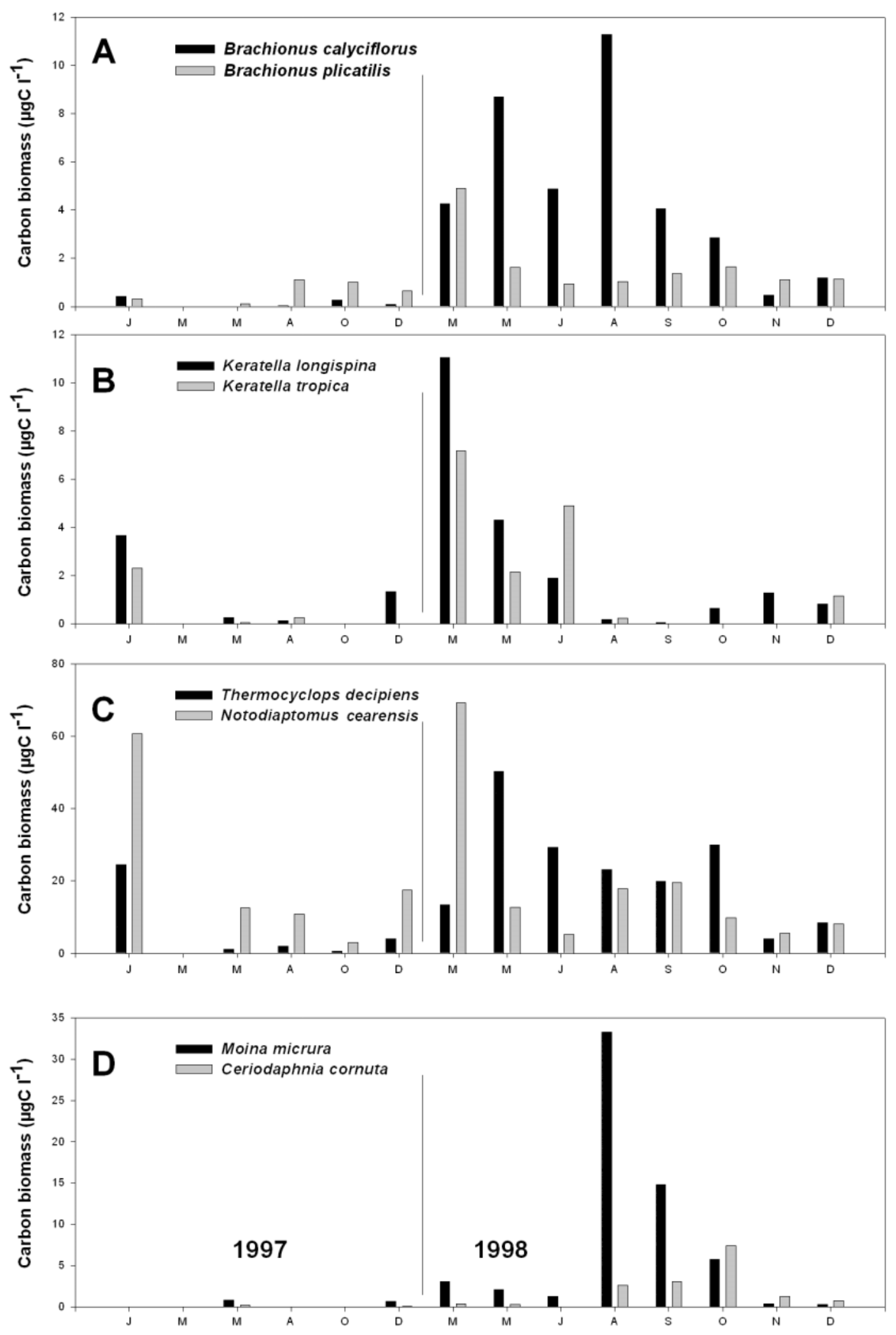

Fig. 9. Seasonal variations of the carbon biomass of zooplankton $\left(\mu \mathrm{g} \mathrm{Cl}^{-1}\right)$ during the survey from January 1997 to December 1998. (A,B) Rotifers (Brachionus calyciflorus, B. plicatilis, Keratella longispina and K. tropica); (C) copepods (Thermocyclops decipiens and Notodiaptomus cearensis); (D) cladocerans (Moina micrura and Ceriodaphnia cornuta) 


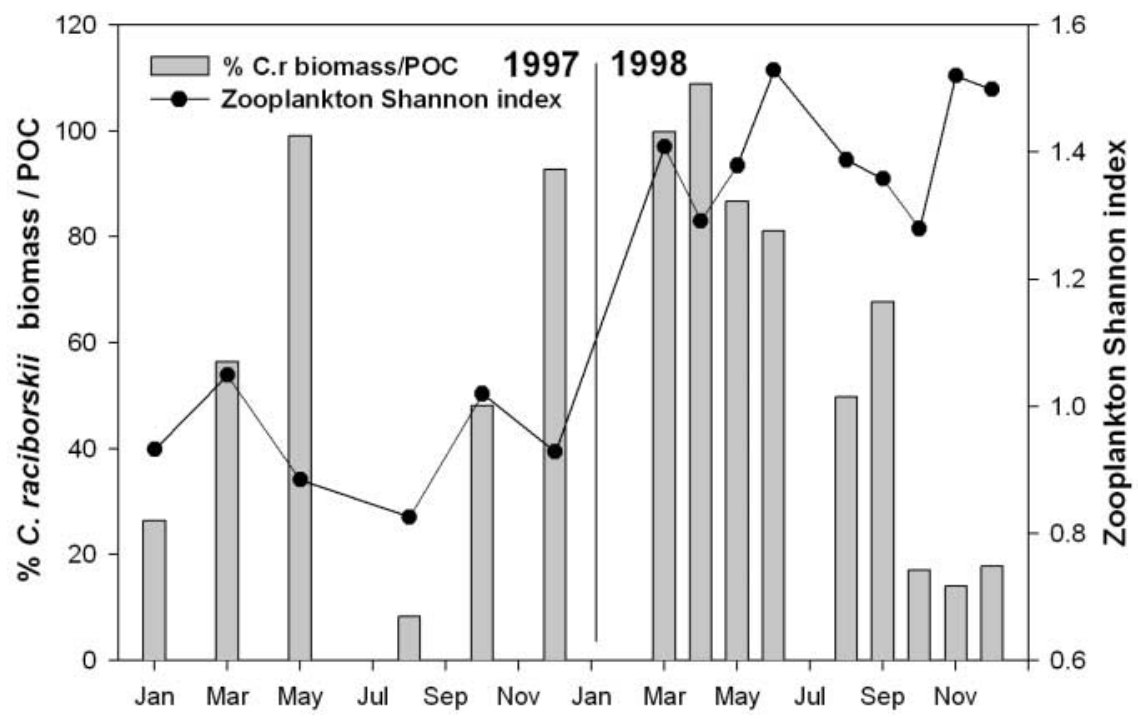

Fig. 10. Time course of the ratio of Cylindrosperompsis raciborskii biomass to POC, and the zooplankton Shannon index during the survey study based on 39 northeast Brazilian reservoirs with a mean of 23 taxa (Bouvy et al. 2000) and the general trend of a decrease of limnetic rotifers and crustacean diversity towards the equator (Fernando \& Paggi 1998).

It is well known that each zooplanktonic species differs in its selective feeding patterns depending mainly on prey size (e.g., Pagano et al. 1999). The cyanobacteria are inedible prey for most species of zooplankton, and only small colonies or dispersed cells of cyanobacteria can be ingested (Jarvis et al. 1987). Very few reports of zooplankton grazing on cyanobacteria, and especially Cylindrospermopsis raciborskii, are available in the literature. Fabbro \& Duivenvoorden (1996) reported the absence of grazing for the dominant

stimulated by cyanobacterial exudates with no toxic effect. Mayer et al. (1997) interpreted very high bacterial numbers during a cyanobacterial bloom (mainly Limnothrix redekei and Cylindrospermopsis raciborskii) in a hypereutrophic temperate lake as the result of the release of labile dissolved organic matter. However, Paerl \& Pinckney (1996) suggested that the toxins may affect several ecological processes including grazing by protists. Similarly, Christoffersen (1996) and Sommaruga \& Robarts (1997) found a decrease in abundance and growth rate of heterotrophic flagellates in a Danish lake during a toxic Microcystis bloom. In our study, there was no evidence that toxins liberated by $C$. raciborskii cells affect the growth of bacteria and nanoflagellates.

\section{Effect of the bloom on zooplankton}

The zooplankton community in Ingazeira reservoir can be characterised by (1) rotifers that dominate in density and number of species (15 taxa), (2) copepods that dominate in terms of biomass and (3) a very low abundance and diversity of cladocerans. This structure of zooplankton community, which is similar to that found in many natural lakes and reservoirs of Brazil (Matsumura-Tundisi 1986, Rocha et al. 1995), is probably largely influenced by fish predation. Recently, Lazzaro et al. (2001) showed that the northeast Brazilian reservoirs were dominated by omnivorous fishes, explaining the predominance of the small-bodied herbivorous cladocerans. The low taxonomic richness of zooplankton (a total of 18 taxa) confirmed the previous coiled forms during a bloom of $C$. raciborskii. Rothhaupt (1991) surmised that Brachionus may be negatively affected by the mechanical (rigid filaments) or biochemical (toxins) properties of C. raciborskii. In contrast, Fulton \& Paerl (1988) showed that some rotifers such as the genus Brachionus seem to be resistant to toxins, and perhaps, according to Kirk \& Gilbert (1992), they have sophisticated taste receptors that enable them to ignore toxic cyanobacteria. Many works have shown that the large cladoceran species (such as Daphnia or Diaphanosoma) were more sensitive to the toxic filamentous cyanobacteria than the small species (Infante \& Riehl 1984, Kirk \& Gilbert 1992). For example, a clear inverse relationship between cladoceran abundance and the biomass of $C$. raciborskii was reported for the Salomon Dam reservoir, Queensland, Australia (Hawkins 1988).

In our study the zooplankton biomass (mainly rotifers and copepods) increased in parallel with Cylindrospermopsis raciborskii during the bloom and decreased drastically after the bloom (Table 4). The biomass of rotifers and copepods, followed by cladocerans, increased markedly during the bloom of toxic cyanobacteria. Furthermore, the zooplankton Shannon index (and especially the rotifer diversity) increased simultaneously with the presence of $C$. raciborskii (Fig. 9). Our experiments conducted in the laboratory and based on grazing of Cylindrospermopsis by different zooplankton groups (by size) revealed that all groups can cut filaments (with a mean decrease of length from $103 \mu \mathrm{m}$ to $69 \mu \mathrm{m}$ after $48 \mathrm{~h}$ of grazing experiments) but only copepods and cladocerans, and less significantly rotifers, can ingest the small lengths of filaments of Cylin- 


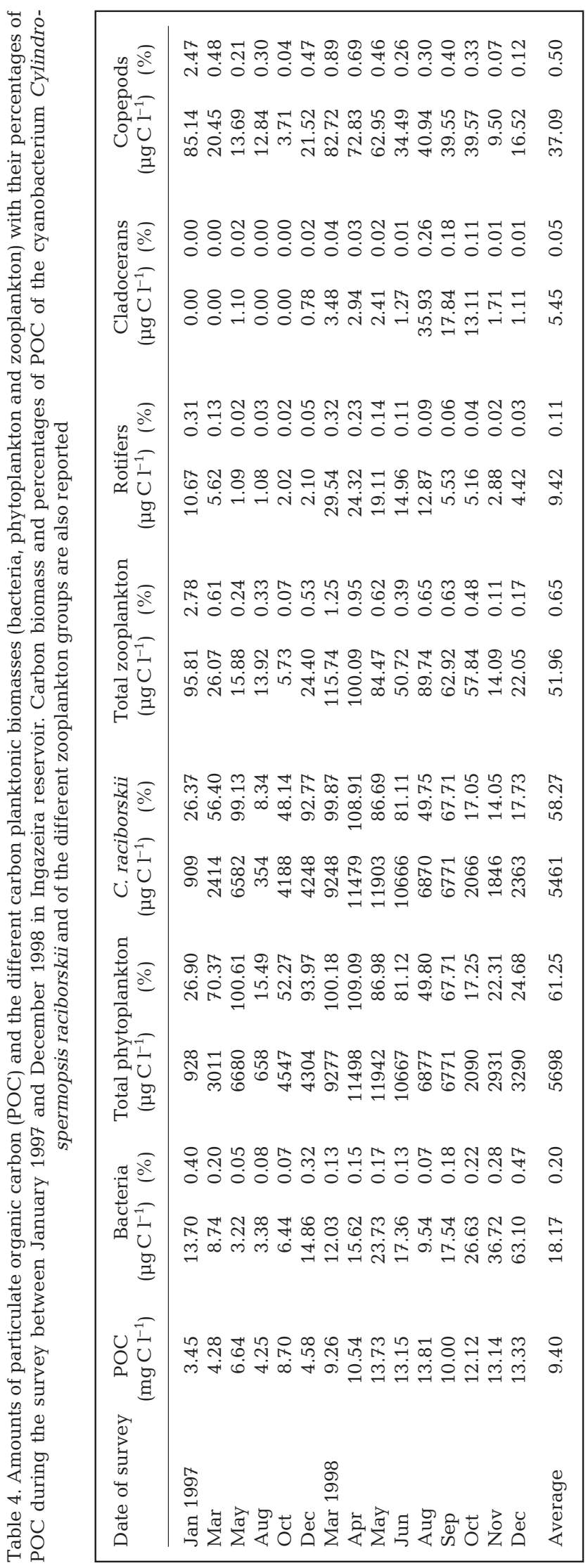

drospermopsis (Bouvy \& Molica 1999). Fig. 3B shows 1 trichome of C. raciborskii after $48 \mathrm{~h}$ of grazing pressure by copepods revealing 2 regions of breakage (see the arrows). This observation corroborates the conclusions reported by Burns \& Xu (1990) and Dawidowicz (1990) on the shortened filaments by grazing of certain species, allowing the later consumption of cyanobacteria by other zooplankton species. According to Boon et al. (1994), filamentous cyanobacteria are more readily consumed by copepods, particularly calanoids, than by cladocerans. Fabbro \& Duivenvoorden (1996) observed grazing of small lengths of $C$. raciborskii by 2 rotifer species (Brachionus calyciflorus and B. angularis) following breakage of larger filaments by Daphnia lumholtzi. Thus, in Ingazeira reservoir, some species of zooplankton (copepods, which dominated the biomass) can shorten filaments (considered as the sole phytoplankton source), allowing the cyanobacteria to be ingested by the smaller zooplankton (rotifers), as corroborated by the positive correlation between these 2 variables $(r=0.66, p=0.006 ; n=15)$.

In fact, a peculiar trophic coupling has been established between zooplankton organisms and Cylindrospermopsis raciborskii. After the bloom there is a sudden development of cladocerans with a maximum increase of the main species, Moina micrura, which can be the consequence of the favourable trophic conditions created by previous fragmentation of cyanobacterial filaments by copepods and rotifers. On the other hand, the observed developments imply that these small-bodied cladocerans (Moina and Ceriodaphnia) in Ingazeira reservoir were not sensitive to the toxic effects of C. raciborskii, as has been shown for Microcystis by Hanazato (1991) in the highly eutrophic Lake Kasumigaura, Japan. Finally, the delay between the peak of copepod abundance and those of cladocerans can be explained by the predation of the small cladocerans by Thermocyclops. Indeed, it is well known that the last copepodite stages and the adults of cyclopoids are carnivorous and can exert a strong predation pressure upon other zooplankton species (Brandl 1998). Thus, simultaneously with the bottomup factors (linked to the resource, e.g., small filaments of C. raciborskii), the cladoceran community can be controlled by the top-down factors exerted by predators. Many planktonic rotifers are relatively unselective, feeding on particles in the size range of 0.5 to $20 \mu \mathrm{m}$, including the nanoflagellates (Rothhaupt 1990). However, the impact of rotifers is generally considered to be much less significant than that of large cladocerans (Arndt 1993) and thus the increase in rotifers during the bloom did not have a negative impact on nanoflagellates. Finally, the absence of the largebodied cladocerans in Ingazeira reservoir can explain the strong predatory control of protozoans on bacterial 
communities because these large filter feeders frequently cause a decrease of heterotrophic and autotrophic nanoplankton (Langenheder \& Jürgens 2001).

To summarise, Cylindrospermopsis raciborskii bloom induces cascading changes in the planktonic structure. Our data suggest the possibility of breakage of filaments by some zooplanktonic species (e.g., copepods) and, as a result of being broken, previously inedible cyanobacterial filaments may be efficiently grazed as small and edible particles by different zooplanktonic species (e.g., cladocerans). Changes in both the phytoand zooplanktonic communities were also associated with shifts in bacterial community composition with the progressive occurrence of large grazing-resistant bacteria. Thus, in a eutrophication context, the cyanobacterial bloom provides a pulse resource for herbivores, implying a significant change in the structure of other planktonic components, but that is not accompanied by a loss of biodiversity.

Acknowledgements. The authors are indebted to the 3 reviewers for their constructive comments and criticisms. Sincere thanks to Renato Molica and Silvia Nascimento (ITEP, Recife/PE, Brazil) for their assistance in the toxicity study. We also thank Mauro Marinho and Simone de Oliveira for their help during the limnological samplings and laboratory work. This work is part of the IRD/UFRPE 'Açudes' Project.

\section{LITERATURE CITED}

Arndt H (1983) Rotifers as predators on components of the microbial web (bacteria, heterotrophic flagellates, ciliates) -review. Hydrobiologia 255/256:231-246

Azevedo SMFO (1996) Toxic cyanobacteria and the Caruaru tragedy. Proc IV Symp Brazilian Soc Toxicol 83

Boon PI, Bunn SE, Green JD, Shiel RJ (1994) Consumption of cyanobacteria by freshwater zooplankton; implications for the success of 'top town' control of cyanobacterial blooms in Australia. Aust J Mar Freshw Res 45:875-887

Borics G, Grigorszki I, Szabo S, Padisák J (2000) Phytoplankton associations under changing pattern of bottom-up vs. top-down control in a small hypertrophic fishpond in East Hungary. Hydrobiologia 424:79-90

Bottrel HH, Duncan A, Gliwicz ZM, Grygierek E, Herzig A, Hillbricht-Ilkowska A, Kurasawa H, Larsson P, Weglenska $\mathrm{T}$ (1976) A review of some problems in zooplankton production studies. Norwegian J Zool 24:419-456

Bouvy M, Molica RJR (1999) Avaliação da ingestão de Cylindrospermopsis pelo zooplâncton: testes em laboratório. Anais do VII Congresso Brasileiro Ficologia, 22-26 September 1999, Porto de Galinhas, Brazil, p 161

Bouvy M, Molica RJR, De Oliveira S, Marinho M, Beker B (1999) Dynamics of a toxic cyanobacterial bloom (Cylindrospermopsis raciborskii) in a shallow reservoir in the semi-arid region of Northeast Brazil. Aquat Microb Ecol 20:285-297

Bouvy M, Falcão D, Marinho M, Pagano M, Moura A (2000) Occurrence of Cylindrospermopsis (Cyanobacteria) in 39 Brazilian tropical reservoirs during the 1998 drought. Aquat Microb Ecol 23:13-27

Branco CWC, Senna PAC (1996) Relations among heterotro- phic bacteria, chlorophyll-a, total phytoplankton, total zooplankton and physical and chemical features in the Paranoa Reservoir, Brasilia, Brazil. Hydrobiologia 337:171-181

Brandl Z (1998) Feeding strategies of planktonic cyclopoids in lacustrine ecosystems. J Mar Syst 15:87-95

Burns CW, Xu Z (1990) Calanoid copepods feeding on algae and filamentous cyanobacteria: rates of ingestion, defaecation and effects on trichome length. J Plankton Res 12: 201-213

Carmichael WW (1994) The toxins of cyanobacteria. Sci Am 270:78-86

Christoffersen K (1996) Ecological implications of cyanobacterial toxins in aquatic food webs. Phycologia 35:42-50

Codd GA (2000) Cyanobacterial toxins, the perception of water quality, and the prioritisation of eutrophication control. Ecol Eng 16:51-60

Cole JJ, Findlay S, Pace ML (1988) Bacterial production in fresh and saltwater ecosystems: a cross-system overview. Mar Ecol Prog Ser 43:1-10

Dawidowicz P (1990) The effect of Daphnia on filament length of blue-green algae. Hydrobiologia 191:265-268

Del Giorgio PA, Gasol JM, Vaqué D, Mura P, Agusti S, Duarte CM (1996) Bacterioplankton community structure-protists control net production and the proportion of active bacteria in a coastal marine community. Limnol Oceanogr 41:1169-1179

de Souza RCR, Carvalho MC, Truzzi AC (1998) Cylindrospermopsis raciborskii (Wolos.) Seenayya et Subba Raju (Cyanophyceae) dominance and a contribution to the knowledge of Rio Pequeno Arm, Billings reservoir, Brazil. Environ Toxicol Water Qual 13:73-81

Dokulil MT, Mayer J (1996) Population dynamics and photosynthetic rates of a Cylindrospermopsis-Limnothrix association in a highly eutrophic urban lake, Alte Donau, Vienna, Austria. Algol Stud 83:179-195

Fabbro LD, Duivenvoorden LJ (1996) Profile of a bloom of the cyanobacterium Cylindrospermopsis raciborskii (Wolosszynska) Seenaya and Subba Raju in the Fitzroy River in tropical central Queensland. Mar Freshw Res 47:685-694

Fernando CH, Paggi JC (1998) Cosmopolitain and latitudinal distribution of freshwater zooplanktonic Rotifera and Crustacea. Verh Int Ver Limnol 26:1916-1917

Fulton RS, Paerl HW (1988) Effects of the blue-green algae Microcystis aeruginosa on zooplankton competitive relations. Oecologia 76:383-389

Gilbert JJ (1996) Effect of food availability on the response of planktonic rotifers to a toxic strain of the cyanobacterium Anabaena flos-aquae. Limnol Oceanogr 42:1565-1572

Gliwicz ZM, Lampert W (1990) Food thresholds in Daphnia species in the absence and presence of blue-green filaments. Ecology 71:691-702

Gragnani A, Scheffer M, Rinaldi S (1999) Top-down control of cyanobacteria: a theoretical analysis. Am Nat 153:59-72

Hanazato T (1991) Interrelations between Microcystis and Cladocera in the highly eutrophic Lake Kasumigaura, Japan. Int Rev Hydrobiol 76:21-36

Hawkins P (1988) The zooplankton of a small tropical reservoir (Solomon Dam, North Queensland): seasonal changes and the influence of water quality management measures. Hydrobiologia 157:105-118

Hawkins P, Lampert W (1989) The effect of Daphnia body size on filtering rate inhibition in the presence of a filamentous cyanobacterium. Limnol Oceanogr 34:1084-1089

Huszar VLM, Silva LHS, Marinho M, Domingos P, Sant'Anna CL (2000) Cyanoprokaryote assemblages in eight productive tropical Brazilian waters. Hydrobiologia 424:67-77

Infante A, Riehl W (1984) The effect of Cyanophyta upon zoo- 
plankton in a eutrophic tropical lake. Hydrobiologia 113: 293-298

Jarvis AC, Hart RC, Combrink S (1987) Zooplankton feeding on size fractionated Microcystis colonies and Chlorella in a hypereutrophic lake (Hartbeespoort Dam, South Africa): implications to resource utilization and zooplankton succession. J Plankton Res 9:1231-1249

Jürgens K, Güde H (1994) The potential importance of grazing-resistant bacteria in planktonic systems. Mar Ecol Prog Ser 112:169-188

Kirk KL, Gilbert JJ (1992) Variation in herbivore response to chemical defenses: zooplankton foraging on toxic cyanobacteria. Ecology 73:2208-2217

Krambeck C, Krambeck KHJ, Overbeck J (1981) Microcomputer assisted biomass determination of plankton bacteria on scanning electron micrographs. Appl Environ Microbiol 42:142-149

Lagos N, Onodera H, Zagatto PA, Andrinolo D, Azevedo SMFQ, Oshima Y (1999) The first evidence of paralytic shellfish toxins in the freshwater cyanobacterium Cylindrospermopsis raciborskii, isolated from Brazil. Toxicon 37:1359-1373

Landry MR, Hass LW, Fagerness V (1984) Dynamics of microbial plankton communities experiments in Kaneohe bay, Hawaii. Mar Ecol Prog Ser 16:127-133

Langenheder S, Jürgens K (2001) Regulation of bacterial biomass and community structure by metazoans and protozoan predation. Limnol Oceanogr 46:121-134

Lazzaro X (1997) Do the trophic cascade hypothesis and classical biomanipulation approaches apply to tropical lakes and reservoirs? Verh Int Ver Limnol 26:719-730

Lazzaro X, Bouvy M, Ribeiro-Filho R, De Olivera V, De Sales LT, De Vasconcelos ARM, Da Mata M (2001) Fish trophic guilds regulate phytoplankton in Brazilian Northeast reservoirs via multi-channel omnivory. Freshw Biol (in press)

Matsumura-Tundisi T (1986) Latitudinal distribution of Calanoida copepods in freshwater aquatic systems of Brazil. Rev Bras Biol 46:527-553

Mayer J, Dokulil MT, Salbrechter M, Berger M, Posch T, Pfister G, Kirschner AKT, Velimirov B, Steitz A, Ulbricht T (1997) Seasonal successions and trophic relations between phytoplankton, zooplankton, ciliate and bacteria in a hypereutrophic shallow lake in Vienna, Austria. Hydrobiologia 342/343:165-174

Molica R, Nascimento S, Bouvy M, Silva N (1998) Neurotoxic Cylindrospermopsis sp. blooms in Brazilian waterbodies. 4th International Conference on Toxic Cyanobacteria, North Carolina, 27 September to 1 October 1998

Moran XAG, Gasol JM., Arin L, Estrada M (1999) A comparison between glass fiber and membrane filters for the estimation of phytoplankton POC and DOC production. Mar Ecol Prog Ser 187:31-41

Nascimento SM, Molica RJR, Bouvy M, Ferreira A, Silva LHS, Huszar V, Azevedo S (2000) Toxic cyanobacterial blooms in the Tapacurá reservoir, Northeast Brazil. 9th International Conference on Harmful Algal blooms, Hobart, Tasmania, 7-11 February 2000

Ohtani I, Moore R, Runnegar MTC (1992) Cylindrospermopsin: a potent hepatotoxin from the blue-green alga Cylindrospermopsis raciborskii. J Am Chem Soc 114: 7941-7942

Padisák J (1997) Cylindrospermopsis raciborskii (Woloszyn-

Editorial responsibility: William Li,

Dartmouth, Nova Scotia, Canada ska) Seenayya et Subba Raju, an expanding, hightly adaptive cyanobacterium: worldwide distribution and review of its ecology. Arch Hydrobiol Suppl 4:563-593

Paerl HW, Pinckney JL (1996) A mini-review of microbial consortia: their roles in aquatic production and biogeochemical cycling. Microb Ecol 31:225-247

Pagano M, Saint-Jean L, Arfi R, Bouvy M, Guiral D (1999) Zooplankton food limitation and grazing impact in a eutrophic brackish-water tropical pond (Côte D'Ivoire, West Africa). Hydrobiologia 390:83-98

Porter KG, Feig YS (1980) The use of DAPI for identifying and counting aquatic microflora. Limnol Oceanogr 25:943-948

Posch T, Simek K, Vrba J, Pernthaler J, Nedoma J, Sattler B, Sonntag B, Psenner R (1999) Predator-induced changes of bacterial size-structure and productivity studied on an experimental microbial community. Aquat Microb Ecol 18: 235-246

Redfield AC (1958) The biological control of chemical factors in the environment. Am Sci 46:205-221

Reynolds CS (1998) What factors influence the species composition of phytoplankton in lakes of different trophic status? Hydrobiologia 369/370:11-26

Rocha O, Sendacz S, Matsumura-Tundisi T (1995) Composition, biomass and productivity of zooplankton in natural lakes and reservoirs of Brazil. In: Tundisi JG, Bicudo CEM, Matsumura-Tundisi T (eds) Limnology in Brazil. Brazilian Limnological Society, Rio de Janeiro, p 152-165

Rothhaupt KO (1990) Resource competition of herbivorous zooplankton, a review of approaches and perspectives. Arch Hydrobiol 118:1-29

Rothhaupt KO (1991) The influence of toxic and filamentous blue-green algae on feeding and population growth of the rotifer Brachionus rubens. Int Rev Hydrobiol 76:67-72

Rott HE (1981) Some results from phytoplankton counting intercalibrations. Schweiz Z Hydrol 43:34-62

Ruiz J (1994) The measurement of size diversity in the pelagic ecosystem. Sci Mar 58:103-107

Ruttner-Kolisko A (1977) Suggestions for biomass calculation of planktonic rotifers. Arch Hydrobiol Beih 8:71-76

Saint-Jean L, Bonou CA (1994) Growth, production, and demography of Moina micrura in brackish tropical fish ponds (Layo, Ivory Coast). Hydrobiologia 272:125-146

Sarnelle O (1993) Herbivore effects on phytoplankton succession in a eutrophic lake. Ecol Monogr 63:129-149

Sas H (1989) Lake restoration by reduction of nutrient loading: expectations, experiences, extrapolations. Academia Verlag Richarz, St Augustin

Simon M, Azam F (1989) Protein content and protein synthesis rates of planktonic marine bacteria. Mar Ecol Prog Ser 51:203-213

Shannon CE, Weaver W (1963) The mathematical theory of communication. Illinios University Press, Urbana

Sommaruga R, Psenner R (1995) Permanent presence of grazing-resistant bacteria in a hypereutrophic lake. Appl Environ Microbiol 61:3457-3459

Sommaruga R, Robarts RD (1997) The significance of autotrophic and heterotrophic picoplankton in hypereutrophic ecosystems. FEMS Microb Ecol 24:187-200

Wang L, Priscu JC (1994) Stimulation of aquatic bacterial activity by cyanobacteria. Hydrobiologia 277:145-158

Worm J, Sondergaard M (1998) Dynamics of heterotrophic bacteria attached to Microcystis spp. (Cyanobacteia). Aquat Microb Ecol 14:19-28

Submitted: May 2, 2001, Accepted: July 30, 2001

Proofs received from author(s): September 21, 2001 